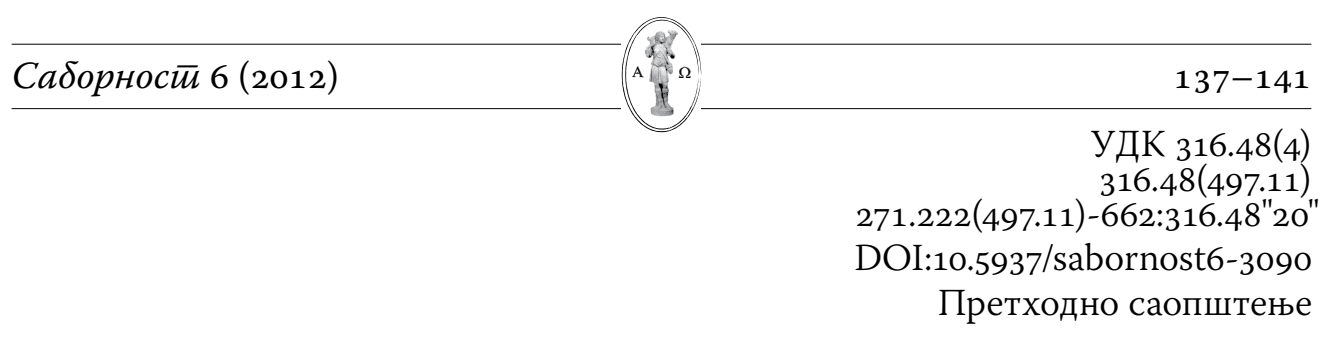

\title{
Zoran Krstić"
}

University of Belgrade, Faculty of Orthodox Theology, Belgrade

\section{Impact of the Economical Crisis on the Social Structure of the European Society ${ }^{1}$}

\begin{abstract}
In this report the author presents his own views on the causes of the economic crisis, the impact it has on Serbian society, as well as the possibilities and ways in which the Church can contribute to dealing with the crisis on the larger, European scale. The paper is divided into four parts. The first, called as The Diagnosis and Analysis of the Current Situation, is about generally accepted reasons for the formation of the crisis, and that the crisis is not only economic and financial, but also a profound moral crisis and life values of the European man. The second part is How the Crisis Affects the Serbian Society analyzes the official facts about the Serbian society, especially the youth unemployment. The third part, Different Possibilities of Interpretation of the Crisis analyzes the opinions of some modern sociologists on the pass of crisis, or it is only about the exhaustion of the European model of the welfare state. The final section discusses the role that the Church and believers can have in overcoming the crisis.
\end{abstract}

Key words: European society, crisis, moral values, welfare state, solidarity.

Y

our Eminence, Venerable Brothers priests, my dear brothers and sistersin Christ, ladies and gentlemen,

It is my pleasure, honor and responsibility to be with you today and on behalf of the Orthodox Church in Serbia participate in the seminar; I hope my humble contribution will help make our joint work fruitful.

It is difficult to touch everything one might say in only ten minutes, all the thoughts and all the feelings, on this ongoing discussion and the problem that have broken into the lives of us all. The presentation I am going to give is split into a few short units, which represent an attempt to analyze and present the social situation in Europe and Serbia and is followed by various possibilities

zorank62@gmail.com

1 Dialog seminar "Promoting Solidarity in the current Economic Crisis: The contribution of the Orthodox Church to the European Social Policy" announcement in Brussels, 17.10.2012. 
of interpretation and, finally, what could be the specific contribution of the Church's eventual exit from the current crisis.

\section{Diagnosis and analysis of the current situation}

Generally accepted diagnosed conditions of most European societies, is that they are shaken by huge or minor economic problems. Our interconnected and interdependent European societies and the states are located in the center of the financial crisis. It also seems that we can easily agree on the causes of the crisis. The Central Committee of the World Council of Churches, convened in Crete one month ago, clearly states: "This crisis is due to various reasons such as unjust economic and financial policies; structural weaknesses of political, economic and financial institutions, and a lack of ethical values in a world that is increasingly dominated by the greed of the powerful seeking short-term advantages and maximum profits and denial of the need of the powerless".

What is important for the Church is the lack of ethical values which marks a very serious cause of the current crisis. So, we are not talking here about the financial or economic crisis only, but the overall crisis of modern European societies in which each of us is, at the same time, both its victim and, by the life values, its cause. For us, the believers, this may not be that surprising, because we always, in the past, present and future, both in the abyss of a crisis and euphoria of well-being, with more or less intensity, see the horror of fallen human nature that needs a necessary healing and what proved through the history in particular - a constant and insatiable human greed. The issue that also all agree about is the need to change the current social situation. The status quo is neither desirable nor possible.

\section{How the crisis affects the society in Serbia}

Emergencies in the modern history of Serbia are not temporary, but permanent condition. The last two centuries of the modern Serbian history have brought brief periods of peace and stability between periods of war, civil strife, the communist tyranny, bombings and the like. The current crisis and its end, which we can not even have a sense of, is not less painful than the previous ones. Figures to illustrate this are brutal and merciless. They turn our attention only to the phenomenon of unemployment and its consequences. According to the latest official data of 2.10.2012, 28.2\% of the population in Serbia is unemployed. What is more indicative is that surveys show that in Serbia today the fear of job loss is greater than the fear of disease. A modern Serb would rather agree to become ill than lose job. This situation has a domino effect both on the society and the private lives of people. If we add into account a high level of corruption and the loss of trust in the government structure, it is getting clear why the formation of disgruntled army and desperate people 
out of patience and hope in human life is quite possible. This new social "underclass" of life-losers potentially generate a destructive force that can transform into anger and violence on a small or large scale. Such course of events is not what anybody wants. The shortest conclusion we can draw is that the economic crisis is shaking the foundations of the fragile and for decades exhausted Serbian society.

Everything presented so far with regards to the European and Serbian societies is known commonplace, and can be read in any serious newspaper. The main question about the present situation, it seems, neither refers to its causes nor its analysis, but whether there is an exit out of the crisis and what place and role in finding a solution the Church can have.

\section{The different possibilities of interpretation of the crisis}

One of the most common interpretations of the crisis is that it is a common occurrence in the cyclical development of the capitalist economy. We have witnessed similar situations earlier in history, and they were ended by new "social contract" that would prevail, at least temporarily, to balance the need for global development and general social welfare. The current situation is identical and we are just in the process of searching for and finding the new social equilibrium. This process should get everyone involved, even the believers and the institutional Church, so as to contribute to promoting solidarity as an ethical virtue in the public sphere. It is quite possible that the things will develop that way, while the current situation is just one more challenge in historical development of the European societies.

However, let's consider a different scenario emerged in the opinions of some modern, primarily contemporary French sociologists, like Alain Touraine (Tyрен, 2011, p. 51), for example: he speaks about the death of classical European social model that has been built for several centuries, in which the society is being understood and interpreted in the social categories. The welfare state, in this interpretation, disappears or necessarily needs to be extremely reduced. This also questions the very, essentially Christian, idea of social solidarity grandly realized in modern Western societies. I am neither a supporter nor opponent of this interpretation, and therefore do not bring up the problem in order to predict the future of European societies. The reason is quite different and lies in search of an answer to the question whether there is a specific and traditional Christian view of solidarity and to answer the question what if the social solidarity falls down? In such view of the events our theme for the dialogue could be rephrased not as how the economic crisis is affecting European societies, but how the structure and the high level objectives of these societies produce the economic crisis. 
140 | Krstić, Z. Impact of the Economical Crisis on the Social Structure of the European Society-

\section{The place and role of the Church in crisis}

I believe that the Church, in a situation of crisis and need for affirmation of solidarity, should take account of the two-level problem to match the old and well-known distinction between concepts of society and community. Social level and the degree of social solidarity do not depend exclusively on Christians. They are just one of the actors in the sphere of social activity, but the actor whose voice needs to be heard, formulated so that the push for a greater degree of social solidarity is not only a good will of people who believe, but rather their obligation to build a new dimension of humanity manifested in the public sphere. However, the success is not guaranteed, and that is why I mentioned the different interpretation of the crisis in order to take into account the possibility of failure.

Let me get back for a moment to the Serbian society and the unemployed. They certainly do not live great but not starving either, not because there is a social solidarity but because there still, although with real problems, functions family solidarity that can support one or more of the unemployed in the family. Solidarity in communities, where the relations between people are direct, personal, has functioned in the past, as well as today and it is the basis of the much needed experience for the wider social solidarity. Do not forget that the Church, like the family, is a community but not society, and the best help to the wider society will be if we, in our church communities, express the Gospel ethos of solidarity.

The process of globalization and European integration bring us closer in space, but does not, as it seems, make us the brothers, though, one should admit, it creates the preconditions for it. A solution that people who believe have to offer as a way out of the crisis, is the mutual human closeness, which we think may be based only upon the faith, in which solidarity is implied, but not required or searched for.

\section{References:}

- Турен, А. (2011). Нова йараяиіма за боље разумеване савременої gрушйва. Београд: ЈП Службени гласник. 


\section{Зоран Крстић}

Универзитет у Београду, Православни ठогословски факултет, Београд

\section{Утицај економске кризе на социјалну структуру европског друштва}

$\mathrm{Y}$ овом саопштењу аутор износи сопствене ставове о разлозима настанка економске кризе, о утицају који она има на српско друштво, а затим разматра могућности и путеве којима Црква може да допринесе бољем суочавању са кризом у ширим, европским размерама. Рад је подељен у че-

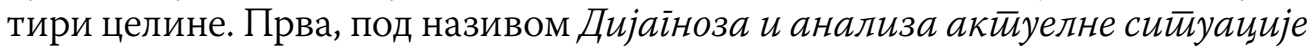
опште прихваћене разлоге настанка кризе, односно да криза није само економска или финансијска већ и дубока криза морала и животних вредности европског човека. Други део, Како криза уйиче на срйско gруийво износи и анализира званичне чињенице о стању српског друштва, а

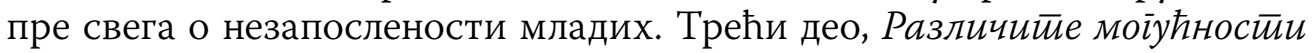

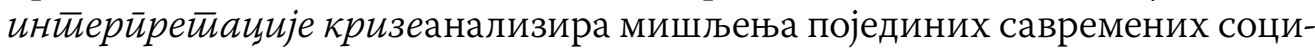
олога о питању пролазности кризе или да се, пак, ради о исцрпљености европског модела државе благостања. Завршни део говори о улози коју Црква и верујући људи могу да имају у превазилажењу кризе.

Key words: европско друштво, криза, моралне вредности, држава благостања, солидарност.

Датум пријема чланка: 9. 12. 2012.

Датум прихватања чланка за објављивање: 12. 12. 2012. 